\title{
Adequate Power Supply: A Must for Effective Teaching of Technological Education
}

\section{ISSN: 2576-8840}

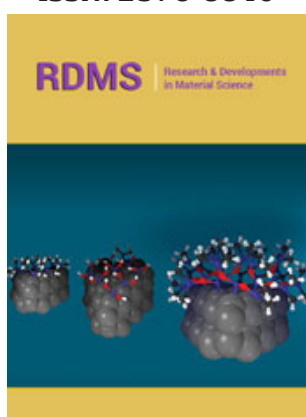

*Corresponding author: Adeoye OS, Department of Electrical/Electronic Engineering, Federal Polytechnic, Ado Ekiti, Nigeria

\section{Submission: 侮 May 19, 2020}

Published: 此June 02, 2020

Volume 13 - Issue 4

How to cite this article: Adebayo AA, Adeoye OS. Adequate Power Supply: A Must for Effective Teaching of Technological Education. Res Dev Material Sci. 13(4). RDMS.000818. 2020. DOI: 10.31031/RDMS.2020.13.000818

Copyright@ Adeoye OS, This article is distributed under the terms of the Creative Commons Attribution 4.0 International License, which permits unrestricted use and redistribution provided that the original author and source are credited.

\author{
Adebayo AA and Adeoye OS*
}

Department of Electrical/Electronic Engineering, School of Engineering, Federal Polytechnic, Ado-Ekiti, Ekiti State, Nigeria

\begin{abstract}
Adequate power supply is found to be missing in Nigeria and this has resulted into a continual lack of supply to the populace. Perennially, it has appear as if the problem of power supply is one that cannot be surmounted and government in and out has always budgeted a large sum of money to the sector and the only result that the people sees is lack of power. Any government coming into governance has always made it part of what they plan to do if voted into elected offices but the only thing the people enjoy is lack of power. The driver of any economy is found to be adequate power supply. Dependency on power supply cannot be overemphasized; both human beings and animals largely depend on it for them to perform optimally. Teaching of technological education is one that is almost impossible without adequate power supply. The method used was the collection of data through the administration of questionnaires. Real time measurements of voltage at the selected laboratories were carried out with the aid of multi meters and plots of voltage deviation against time with the aid of Microsoft spread sheets. Also, data showing the period of power supply and outage for a certain period of time in order to verify the adequacy of power supply to the selected area under consideration. This paper takes proffer solutions by the way of use of solar panels, generating sets and uninterruptible power supply to overcome all these challenges.
\end{abstract}

Keywords: Power supply; Technology; Education; Effective; Teaching; Alternatives

\section{Introduction}

Power balance is not achievable in Nigeria because there is insufficient power generation which can match the power demand in the country and this has led the country to lack of adequate power supply to the people [1]. Adequate power supply in Nigeria is found to be missing and this has led to lack of continuous electricity supply to the people and this is worrisome to the populace in the face of enormous human and material resources. The power supply is challenged with inadequacy due to faulty switch gears, wrong and inadequate sizing of conductors, weak grid network, transformers and feeder faults as well as non payments of tariffs by consumers to the distribution companies [2]. The power is a strategic sector that can regulate the economy in a positive or negative way depending on the rate of supply [3,4]. Unreliable and unstable power supply is major problem which affect economic development negatively. This negative effect on the economy is a trend on other sectors of lives which include political, social, educational sector and particularly technical education in achieving optimal delivery. The factors that determine the status of energy supply to an area are the quantum of energy supply, power generation level, the technology applied, electricity demand, and institutional framework for power generation, supply and demand with policy $[5,6]$. The prosperity of the nations of the world is measured by constant availability of power supply [7]. 58\% of Nigeria's population have access to the national electricity grid and about $30 \%$ of its current requirements are met thereby showing gross power supply inadequacy to the citizens of this country $[8,9]$. The components of power system are generation, transmission, distribution and utilization of electrical energy [10]. The operating voltages for generation, transmission, sub-transmission, primary distribution, secondary distribution, three phase consumers and single phase consumers are $16 \mathrm{kV}, 330 \mathrm{kV}, 132 \mathrm{kV}, 33 \mathrm{kV}, 11 \mathrm{kV}, 415 \mathrm{~V}$ and $240 \mathrm{~V}$ respectively [11]. A study shows how reliable the power supply in different areas in Ekiti State such as Erinfun; Adehun; Aba; FPA; CBN; Abekoko and others with power disruption of 182.5 hours, 2190 hours, 233.75 hours, 4015 hours, and 8760 hours in a particular year in a respective manner. This signifies $2.08 \%, 25 \%, 2.6 \%, 45 \%, 100 \%$ power supply disruption 
level in one year and of course this will in turn adversely affect educational institution or even Schools in these areas [12]. Power supply can be subdivided into domestic and this includes lighting points, fans, heaters, television set, small motor for pumping of water. Municipal power demand includes street-lighting, water supply and drainage purposes. Irrigation loads are electric power supply for required for pumps to supply water for agricultural purposes. These loads are found in any technical Schools. The demand of electricity is high in the early hours of each day when citizens prepare for the days' work while there is decrease in electricity demand when the citizens are in their different places of work and it increases again when they come back home in the night [13].

The technical education institutions are of different types. These are university, pre-vocational and vocational school, the technical colleges, the polytechnics and college of technology, and technical teacher education at post secondary level [14]. Technical education is a requirement for training middle level manpower need for the country [15]. Effective teaching deals with the ability of teachers in striving to guide and involve their students in learning activities rather than positing that some students cannot perform brilliantly by the way of destiny. A teacher that is effective believes in the ability of every student to be successful. The components of effective teaching are acceptability of capacity of individuals, pedagogies, progress monitoring and accessing feedbacks, exposing students to be responsible, mastery of course contents by teachers, making available suitable environmental conditions, and building positive relationships between students and teachers [16]. Technological education is the study in which students learn about the processes and knowledge related to technology. The trend of technological education today is the use of internet facilities, personal computers, projectors and other teaching facilities to demonstrate different topics in each subject in a way that Students will have good understanding. However, this seems to be a mirage in this part of the world due to inadequate power supply to various parts of the country $[15,16]$. Adequate power supply is required to effectively and efficiently run a technological education in every part of the world and more importantly in the developing nations of the world like Nigeria.

\section{Methodology}

The method employed in analyzing the adequacy of power supply was based on the use of the laboratories of the Federal Polytechnic, Ado-Ekiti as a case study. The administration of 600 questionnaires was distributed among students and staff of the institution. 500 out of the 600 distributed questionnaires were returned representing $83.33 \%$. The application of simple percentage of collected data to the overall returned questionnaire was used to carry out the analysis in order to assess the adequacy of power supply to the area of study. The use of internet facilities and relevant literatures were utilised in carrying out review. Data of power supply were obtained from the maintenance unit of the Federal Polytechnic, Ado-Ekiti to verify the level of power adequacy in the laboratories. Multi meters were used to measure the voltage supply at six laboratories of Electrical and Electronic Department for a certain period of time. The measured voltages are expected to be within the IEEE standard of $\pm 6 \%$ range of the expected nominal voltage of $240 \mathrm{~V}$. Therefore, a voltage deviation is estimated with the standard model as shown. Each of the measured voltage at a particular interval of ten minutes was estimated for the six laboratories and plots of estimated voltage deviations against time with the aid of Microsoft excel spreadsheet.

$$
\mathrm{U}_{\mathrm{dev}}=\frac{U_{\text {nom }}-U_{\text {measured }}}{U_{\text {nom }}} \times 100 \%
$$

Where $U_{\text {dev }}$ is the percentage voltage deviation, $U_{\text {measured }}$ is the measured voltage and $U_{\text {nom }}$ is the nominal voltage and it is assumed to be $240 \mathrm{~V}$.

\section{Review of Literatures}

\section{Effective teaching strategies and technology education curriculum}

Teachers are traditionally the custodians of knowledge and their function is to majorly transfer skills and knowledge to students. Information is readily available on internet in such a way that there is a shift from the traditional approach because it can be accessed anytime, anywhere and any day. Effective teaching ensures that the traditional approach is substituted by deeper and pragmatic learning methods through analysis, development, creativity and demonstrative understanding [17].

The effective teaching and strategies are under listed:

1. Interest and explanation: Interest and explanation in effective teaching is increased in educational activities and this makes participants to work hard. The instructors make explanations that will allow the understanding of students [18].

2. Students learning in terms of concern and respect: Poor teaching is about lack of interest and compassion from the side of the students in learning. Poor teaching is triggered by lack of preparation by teachers, lack of interest and motivation. Compassion on the side of the students depend on present economic realities, peer influence, and the fact that the students know that after leaving school, there is no job available for them. Good teaching is about simplifying the course with benevolence and humility, helping students to become masters and successful [18].

3. Accurate assessment and feedback: It is about assessment methods and ensuring students to showcase their expertise of the subject in different ways. Power of feedback is encouraged and students are not allowed to memorize and regurgitate. This is achievable by the way of utilizing discussion methods, descriptive, demonstrative approach, take home assignments, teaching and even lecturing methods [18].

4. Definite goals and intellectual approach: Effective teaching sets high standards for students, presents definite goal; make students to have the idea of the course contents and the expected results are achievable [18]. 
5. Active engagement, Independence and control: Effective teaching gives students the active engagement in learning, an independent mind in reasoning and control in learning [18].

6. Interactive learning approach on the side of students: Effective teaching exposes students to interactive learning to produce better results [18].

Technological education curriculum is designed to match students' interest and intellectual development at different key stages:

a) Stages 1 and 2 are made up of awareness and exploration.

b) Stage 3 is made up of exploration, experience and familiarisation.

c) Stage 4 and beyond are made up of exploring orientation for life longing learning and specialisation [19].

\section{Challenges with power supply in technological education}

1. Inadequate funding: Funds are required for maintenance of the grid system and its expansion. Repairs on the lines and the substation when there are faults require some funding Nigeria has not been able to meet the UNESCO standard in term of budgetary allocation with the peak allocation of $9.94 \%$ in 2014 as shown in Table1.

2. Capacity of the grid: The capacity of the grid should be determined at the point of design by the indices of good design of power network which are reliability and cost. If the grid strength is weak, the need for re-configuration may be required to make power supply to be adequate.

3. Lack of functional alternative power supply: Alternative source of power is important in making available sufficient power when there is power surge. The injection of renewable power sources and generators will aid availability of power supply.

4. Power supply from distribution companies (Discos): Supply of power must be in consonance with reliability index which signifies that when there is power failure, it must be restored automatically through functional back up scheme.

5. Planning: Nigeria generally has problem with planning in the power sector: The per capital demand of each community is crucial and the population size of the institution, also it is important to note the population growth per annum of each institution in the country. This should not exempt higher school of learning at the point of designing the electrical network of such educational environment particularly, technological education communities.

6. Power system faults: Power systems faults are divided into internal and external faults. The faults include instability of exciters due to sudden load increase and armature reaction; complete field loss which makes synchronous generators to pull out of synchronism, deterioration of insulation; damage due to natural effects such as bird perching on the lines: felling of trees on the lines, windstorm; faults generated due to sudden switching or other disturbances in the system: collapse of insulation due to lighting strokes $[20,21]$.

7. Unavailability of teaching/ learning equipment: Lecturers, Technologist and Students need access to constant power supply, laptops, and projectors for effective teaching and learning of technological education.

\section{Ways to mitigate inadequacies in technological education}

1. Funding of technological/technical education should be adequate.

2. The grid capacity must be determined at the point of design in order to achieve adequacy.

3. There must be functional alternate power source such as generating sets and even solar inverters or other renewable energy sources.

4. The power supply from Discos should be adequate and constantly available.

5. The Planning scheme of the Discos should be such that is able to take care of increase in population which solves the problem of future expansion.

6. Faults are inevitable in power system; hence, proper protection schemes should be in place to sensitize the operators.

7. Teaching and learning equipment should be adequately provided for teachers and students in Technological Education for effective teaching and learning.

\section{Discussion}

Table 1 shows the budgetary allocation of education sector in Nigeria ranging from 2009 to 2018. It is a clear picture of the paltry allocation to education sector. The highest allocation was in 2014 with $9.94 \%$ of total budget for that year. It is obvious from the table that the mean value of budgetary allocation to education is $7.32 \%$. There was a sharp decline of education allocation from 2009 to 2010 with correspondent reduction from $7.25 \%$ to $4.83 \%$ of the entire budget. From 2010-2014, there were improvements on education allocation from $4.83 \%$ to $9.94 \%$. However, the allocation to education reduced from $9.94 \%$ to $7.74 \%$ in 2015 . The percentage allocation to the sector increased from 6.10 to $7.38 \%$ and later reduced to $7.03 \%$ in 2016, 2017 and 2018 respectively. In 2018, there was a declaration by the Federal Ministry of Education that funding of education at all levels in Nigeria is below the benchmark recommended by the United Nations Education Scientific and Cultural Organisation (UNESCO) of $26 \%$ of national budget and $6 \%$ of gross national domestic products (GDP). From Table $2 \& 3,475$ respondents agreed that power supply adequacy affect conduct of practical in the laboratories in the School of Engineering while 25 disagreed. The percentage equivalence of those who agreed was $95 \%$ while only $5 \%$ disagreed. The level of power supply adequacy was classified into mild effect, fair effect and high effect and the percentage equivalence were $5 \%, 65 \%$ and $30 \%$ respectively. $90 \%$ of respondents noted that power supply in-adequacy affect the 
conduct of practical in the laboratory while $10 \%$ of respondents did not agree. 55\% of respondents agreed that the effect of inadequate power supply is grossly negative on the side of the students and technologists while $45 \%$ did not see any negative impact on the personnel and students. $50 \%$ of respondents opined that power supply to the laboratories stated that power supply to the study area is between 5 and 8 hours while $10 \%$ of respondents noted that power supply is above 8 hours daily. $50 \%$ of respondents agreed that power failure on daily basis is between 1 and 4 hours, 35\% of respondents agreed with power failure of between 5 and 8 hours, while $15 \%$ of respondents noted that power failure is above 8 hours. $95 \%$ of respondents agreed that the effect of inadequate power supply is enormous and the impact is not positive on both sides of the students and the technologists while 5\% did not agree. $75 \%$ of respondents agreed that power supply inadequacy have negative effect on the submission of their practical reports. $16 \%$ of the respondents agreed that the negative effect is on the technologists while they collate the results. $60 \%$ of the respondents recommended installation of gas power plants as an alternative measure, 20\% recommended solar panel and the remaining 20\% recommended inverters. $16 \%$ of respondents opined that the negative effect is on the collation of their results by the technologists and $9 \%$ of respondents were indifferent. $65 \%$ of respondents agreed that the negative effect of inadequate power supply is high on the overall performance of the institution while 35\% disagreed on its negative impacts. The evaluated voltage deviations for the six laboratories show that there are pollutions in the grid system that is the values exceed the $\pm 6 \%$ of the nominal voltages based on IEEE regulations. The quality of voltage is not really poor but can be said to be fair. This means that very sensitive equipment can be affected thereby altering the orientation of the components. For example, the plot for control laboratory shows a trend that seems to be like a sinusoidal curve as shown in Figure 1 \& 2 represents the plot of time against voltage deviation of machines laboratory. Figure $3 \& 4$ represent the plots of time against voltage deviation for power and telecommunication laboratories respectively. Figure 5 \& 6 show the plots of time against voltage deviation for basic electricity and electronics laboratories respectively. Table 4 is the representation of power supply from Distribution Company, the alternative supply from generating set and the complete supply from both Distribution Company and generating set from 8am to $4 \mathrm{pm}$ for forty-five days. The table verifies that there is power supply in the six laboratories between the hours of $8 \mathrm{am}$ and $4 \mathrm{pm}$ for the period under consideration. Table 4 verifies the position of 200 respondents who noted that power supply to the laboratories is between 5 and 8 hours. More importantly, it verifies more the opinion of 50 respondents that opined that power supply is more than 8 hours on daily basis. This verification is put at percentage equivalence of $40 \%$ for $5-8$ hours and $10 \%$ for above 8 hours. Table 4 shows that the average power supply between $8 \mathrm{am}$ and $4 \mathrm{pm}$ for a period of forty-five days through Distribution Company and generating set is 8 hours (Table 5-10).

Table1: Federal government allocation to education (2009-2018).

\begin{tabular}{|c|c|c|c|c|}
\hline S/N & Year & Budget(Trillion ) & Education Allocation(Billion N) & Percentage of Budget (\%) \\
\hline 1. & 2009 & 3.049 & 221.19 & 7.25 \\
\hline 2. & 2010 & 5.160 & 249.09 & 4.83 \\
\hline 3. & 2011 & 4.972 & 306.3 & 6.16 \\
\hline 4. & 2012 & 4.877 & 400.15 & 8.20 \\
\hline 5. & 2013 & 4.962 & 426.53 & 8.55 \\
\hline 6. & 2014 & 4.962 & 493 & 9.94 \\
\hline 7. & 2015 & 5.068 & 392.2 & 7.74 \\
\hline 8. & 2016 & 6.061 & 369.6 & 6.10 \\
\hline 9. & 2017 & 7.444 & 550 & 7.38 \\
\hline 10. & 2018 & 8.612 & 605.8 & 7.03 \\
\hline- & Total & 55.19 trillion & 3.90 trillion & 7.32 \\
\hline
\end{tabular}

Source: [21]

Table 2: Analysis of data collection on power supply to engineering laboratories in federal polytechnic, Ado-Ekiti.

\begin{tabular}{|c|c|c|c|c|}
\hline $\mathbf{S} / \mathbf{N}$ & Content of Questionaire & No of Respondents & No of Respondents & No of Respondents \\
\hline 1. & Does power supply affect Students Practical & 475 agreed & 25 disagreed & 0 \\
\hline 2. & Degree of lack of power to Laboratories & 25 mildly & 325 fairly & 150 highly \\
\hline 3. & $\begin{array}{l}\text { Does Power inadequacy affect the output of } \\
\text { Technologists }\end{array}$ & 450 agree & 50 disagreed & 0 \\
\hline 4. & $\begin{array}{l}\text { Does inadequate power supply affect output of } \\
\text { Technologists positively or negatively }\end{array}$ & 225 positively & 275 negatively & 0 \\
\hline 5. & Hours of power supply per day & 250 agreed with $1-4$ hours & 200 agreed with 5-8 hours & 50 agreed with above 8 hours \\
\hline
\end{tabular}




\begin{tabular}{|c|c|c|c|c|}
\hline 6. & Hours of Power failure per day & 250 agreed with $1-4$ hours & 175 agreed with $5-8$ hours & 75 agreed with above 8 hours \\
\hline 7. & $\begin{array}{l}\text { Does inadequate power supply affect Students } \\
\text { output }\end{array}$ & 475 agreed & 25 disagreed & 0 \\
\hline 8. & $\begin{array}{l}\text { How does inadequate power supply affect } \\
\text { Students output }\end{array}$ & $\begin{array}{l}375 \text { agreed that power in- } \\
\text { adequacy affect their report } \\
\text { submission }\end{array}$ & $\begin{array}{l}80 \text { believed that the effect is } \\
\text { majorly on the collation of } \\
\text { their results by Technologist }\end{array}$ & 45 were indifferent \\
\hline 9. & $\begin{array}{l}\text { Does power inadequacy has effect on overall } \\
\text { performance of School }\end{array}$ & 325 agreed & 175 disagreed & - \\
\hline 10. & $\begin{array}{l}\text { Recommendation on how to achieve power } \\
\text { adequacy in the institution }\end{array}$ & $\begin{array}{l}300 \text { recommended installa- } \\
\text { tion of gas power plant }\end{array}$ & $\begin{array}{l}100 \text { recommended installa- } \\
\text { tion of solar panels. }\end{array}$ & $\begin{array}{l}100 \text { recommended installation } \\
\text { of inverters }\end{array}$ \\
\hline
\end{tabular}

Table 3: Percentage equivalence for analysis of data collection on power supply to engineering laboratories in federal polytechnic, Ado-Ekiti.

\begin{tabular}{|c|c|c|c|c|c|c|c|}
\hline S/N & Content of Questionaire & $\begin{array}{c}\text { No of } \\
\text { respondents }\end{array}$ & $\%$ Equivalence & $\begin{array}{c}\text { No of } \\
\text { respondents }\end{array}$ & $\%$ Equivalence & $\begin{array}{c}\text { No of } \\
\text { respondents }\end{array}$ & $\%$ Equivalence \\
\hline 1. & $\begin{array}{l}\text { Does power supply affect } \\
\text { Students Practical }\end{array}$ & 475 & 95 & 25 & 5 & 0 & 0 \\
\hline 2. & $\begin{array}{l}\text { Degree of lack of power to } \\
\text { Laboratories }\end{array}$ & 25 & 5 & 325 & 65 & 150 & 30 \\
\hline 3. & $\begin{array}{l}\text { Does Power inadequacy } \\
\text { affect the output of } \\
\text { Technologists }\end{array}$ & 450 & 90 & 50 & 10 & 0 & 0 \\
\hline 4. & $\begin{array}{l}\text { Does inadequate power } \\
\text { supply affect output of } \\
\text { Technologists positively or } \\
\text { negatively }\end{array}$ & 225 & 45 & 275 & 55 & 0 & 0 \\
\hline 5. & $\begin{array}{l}\text { Hours of power supply } \\
\text { per day }\end{array}$ & 250 & 50 & 200 & 40 & 50 & 10 \\
\hline 6. & $\begin{array}{l}\text { Hours of Power failure } \\
\text { per day }\end{array}$ & 250 & 50 & 175 & 35 & 75 & 15 \\
\hline 7. & $\begin{array}{l}\text { Does inadequate power } \\
\text { supply affect Students } \\
\text { output }\end{array}$ & 475 & 95 & 25 & 5 & - & - \\
\hline 8. & $\begin{array}{l}\text { How does inadequate } \\
\text { power supply affect } \\
\text { Students output }\end{array}$ & 375 & 75 & 80 & 16 & 45 & 9 \\
\hline 9. & $\begin{array}{l}\text { Does power inadequacy } \\
\text { has effect on overall } \\
\text { performance of institution }\end{array}$ & 325 & 65 & 175 & 35 & 0 & 0 \\
\hline 10. & $\begin{array}{l}\text { Recommendation on how } \\
\text { to achieve power adequacy } \\
\text { in the institution }\end{array}$ & 300 & 60 & 100 & 20 & 100 & 20 \\
\hline
\end{tabular}

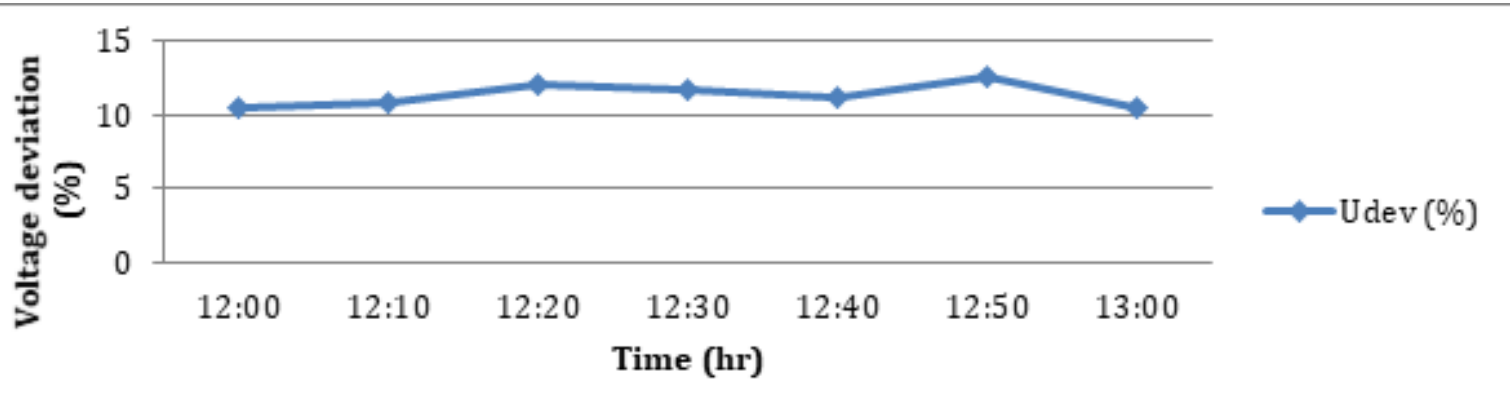

Figure 1: Plot of voltage deviation against time for control laboratory. 


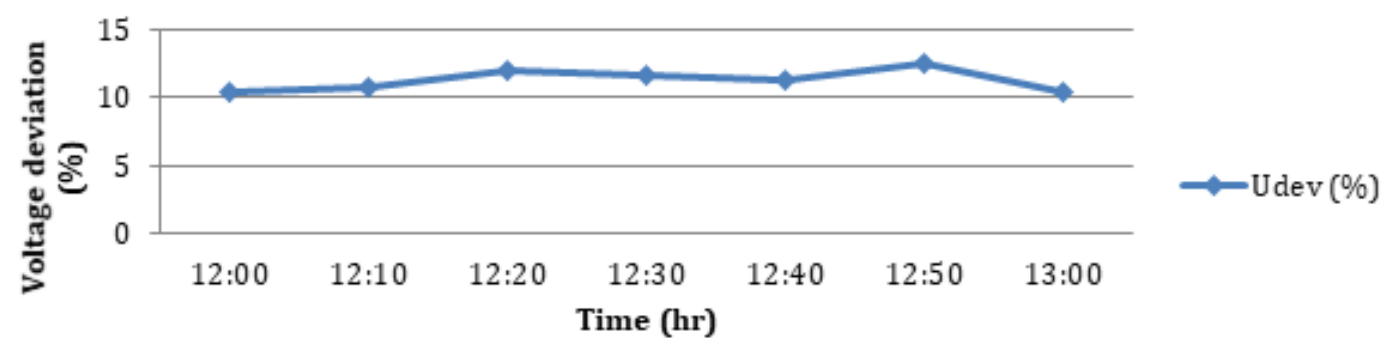

Figure 2: Plot of voltage deviation against time for machines laboratory.

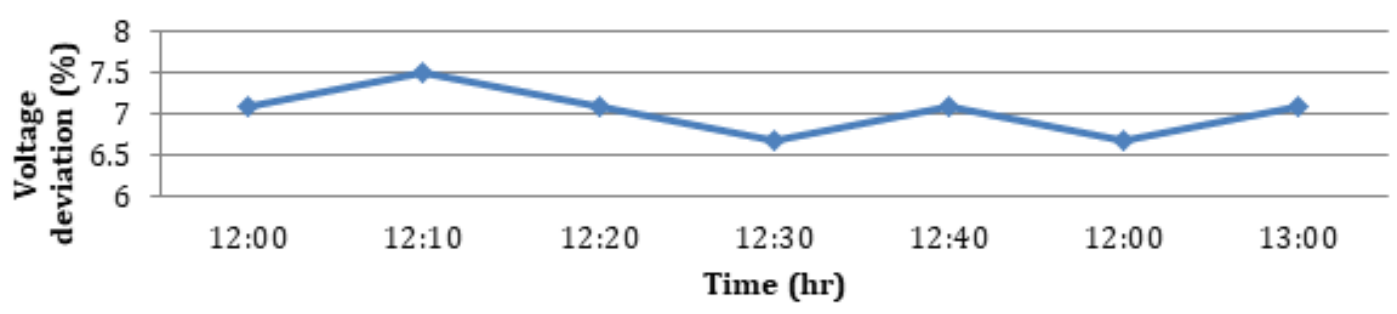

Figure 3: Plot voltage deviation against time for power laboratory.

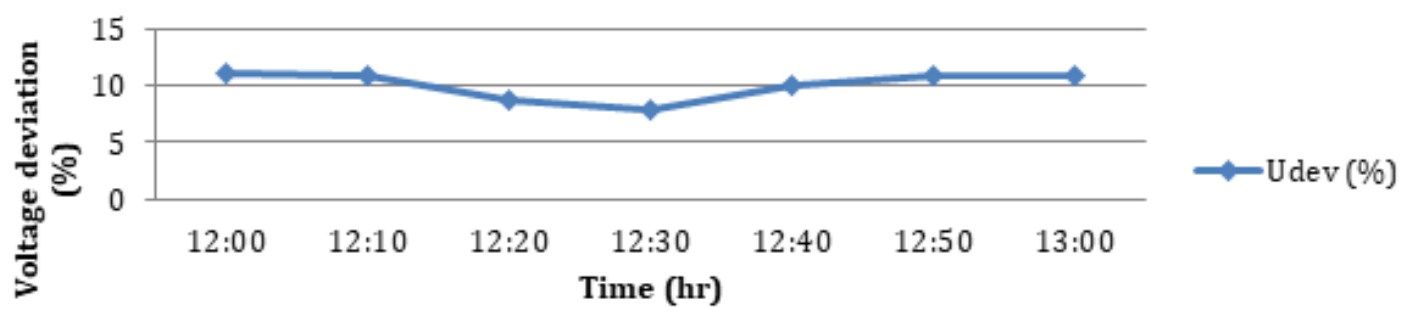

Figure 4: Plot voltage deviation against time for telecommunication laboratory.

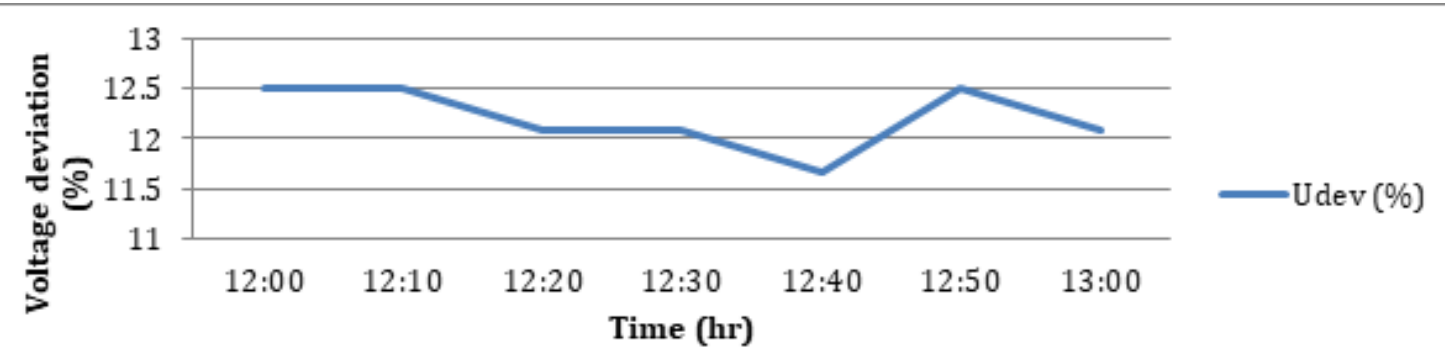

Figure 5: Plot of voltage deviation against time for basic electricity laboratory.

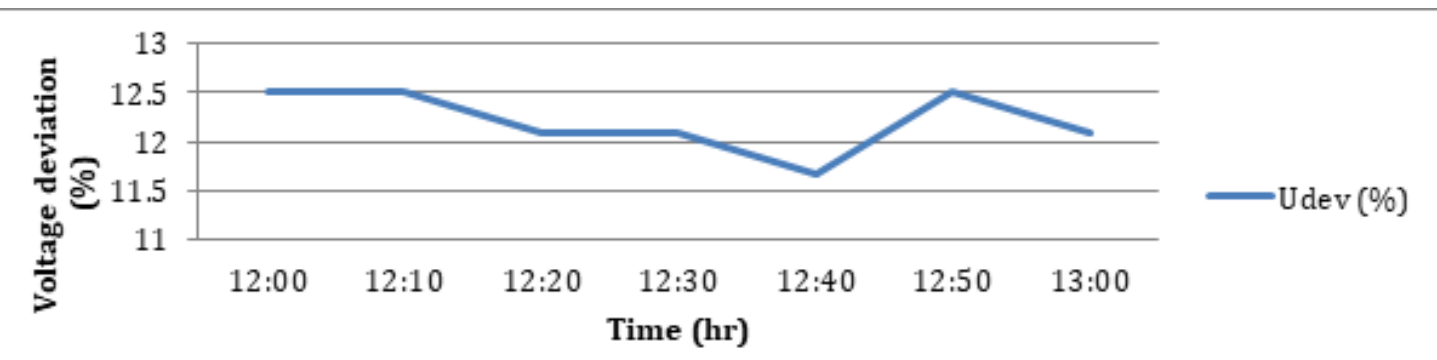

Figure 6: Plot of voltage deviation against time for electronics laboratory. 
Table 4: BEDC and generating set supplies to abuja area of federal polytechnic, Ado-Ekiti extracted from daily fuel consumption chart (Abuja Chart).

\begin{tabular}{|c|c|c|c|}
\hline Date & BEDC Supply (hr) & Generating Set (hr) & BEDC and Generating Set (hr) between $8 \mathrm{am}$ and $4 \mathrm{pm}$ \\
\hline 01-02-2020 & 8.40 & 15.20 & 8 \\
\hline 02-02-2020 & 21.05 & 2.55 & 8 \\
\hline 03-02-2020 & 23.31 & 0.29 & 8 \\
\hline 04-02-2020 & 24.00 & 0 & 8 \\
\hline 05-02-2020 & 22.55 & 1.05 & 8 \\
\hline 06-02-2020 & 23.38 & 0.22 & 8 \\
\hline $07-02-2020$ & 24.00 & 0 & 8 \\
\hline $08-02-2020$ & 20.50 & 3.10 & 8 \\
\hline 09-02-2020 & 23.45 & 0.15 & 8 \\
\hline $10-02-2020$ & 23.18 & 0.42 & 8 \\
\hline $11-02-2020$ & 23.29 & 0.31 & 8 \\
\hline $12-02-2020$ & 24.00 & 0 & 8 \\
\hline $13-02-2020$ & 23.50 & 0.10 & 8 \\
\hline $14-02-2020$ & 22.18 & 1.42 & 8 \\
\hline $15-02-2020$ & 24.00 & 0 & 8 \\
\hline $16-02-2020$ & 19.55 & 4.05 & 8 \\
\hline $17-02-2020$ & 24.00 & 0 & 8 \\
\hline $18-02-2020$ & 21.03 & 2.57 & 8 \\
\hline $19-02-2020$ & 24.00 & 0 & 8 \\
\hline $20-02-2020$ & 20.50 & 3.10 & 8 \\
\hline 21-02-2020 & 21.43 & 2.17 & 8 \\
\hline $22-02-2020$ & 24.00 & 0 & 8 \\
\hline $23-02-2020$ & 24.00 & 0 & 8 \\
\hline $24-02-2020$ & 23.20 & 0.40 & 8 \\
\hline $25-02-2020$ & 24 & 0 & 8 \\
\hline $26-02-2020$ & 20.45 & 3.15 & 8 \\
\hline $27-02-2020$ & 24 & 0 & 8 \\
\hline $28-02-2020$ & 23.38 & 0.22 & 8 \\
\hline $29-02-2020$ & 23.43 & 0.17 & 8 \\
\hline 01-03-2020 & 20.50 & 3.10 & 8 \\
\hline $02-03-2020$ & 16.42 & 7.18 & 8 \\
\hline $03-03-2020$ & 14.58 & 9.02 & 8 \\
\hline 04-03-2020 & 23.40 & 0.20 & 8 \\
\hline $05-03-2020$ & 21.04 & 2.56 & 8 \\
\hline 06-03-2020 & 21 & 3 & 8 \\
\hline $07-03-2020$ & 21.30 & 2.30 & 8 \\
\hline 08-03-2020 & 24 & 0 & 8 \\
\hline 09-03-2020 & 24 & 0 & 8 \\
\hline $10-03-2020$ & 23.16 & 0.44 & 8 \\
\hline $11-03-2020$ & 23.30 & 0.30 & 8 \\
\hline $12-03-2020$ & 24 & 0 & 8 \\
\hline $13-03-2020$ & 23.45 & 0.25 & 8 \\
\hline $14-03-2020$ & 23.55 & 0.5 & 8 \\
\hline $15-03-2020$ & 24 & 0 & 8 \\
\hline
\end{tabular}


Table 5: Measured voltage and evaluated percentage voltage deviation at time interval for basic electricity laboratory.

\begin{tabular}{|c|c|c|}
\hline Time (hr) & Umeasd (V) & U dev (\%) \\
\hline $12: 00$ & 208 & 13.33 \\
\hline $12: 10$ & 206 & 14.17 \\
\hline $12: 20$ & 204 & $15 . .00$ \\
\hline $12: 30$ & 206 & 14.17 \\
\hline $12: 40$ & 207 & 13.75 \\
\hline $12: 50$ & 209 & 12.92 \\
\hline $13: 00$ & 205 & 14.58 \\
\hline
\end{tabular}

Table 6: Measured voltage and evaluated percentage voltage deviation at time interval for basic electronics laboratory.

\begin{tabular}{|c|c|c|}
\hline Time (hr) & Umeasd (V) & U dev (\%) \\
\hline $12: 00$ & 210 & 12.50 \\
\hline $12: 10$ & 210 & 12.50 \\
\hline $12: 20$ & 211 & 12.08 \\
\hline $12: 30$ & 211 & 12.08 \\
\hline $12: 40$ & 212 & 11.67 \\
\hline $12: 50$ & 210 & 12.50 \\
\hline $13: 00$ & 211 & 12.08 \\
\hline
\end{tabular}

Table 7: Measured voltage and evaluated percentage voltage deviation at time interval for control laboratory.

\begin{tabular}{|c|c|c|}
\hline Time (hr) & Umeasd (V) & U dev (\%) \\
\hline $12: 00$ & 213 & 11.25 \\
\hline $12: 10$ & 214 & 10.83 \\
\hline $12: 20$ & 219 & 8.75 \\
\hline $12: 30$ & 221 & 7.91 \\
\hline $12: 40$ & 216 & 10.00 \\
\hline $12: 50$ & 214 & 10.83 \\
\hline $13: 00$ & 214 & 10.83 \\
\hline
\end{tabular}

Table 8: Measured voltage and evaluated percentage voltage deviation at time interval for telecommunication laboratory.

\begin{tabular}{|c|c|c|}
\hline Time (hr) & Umeasd (V) & U dev (\%) \\
\hline $12: 00$ & 223 & 7.08 \\
\hline $12: 10$ & 222 & 7.5 \\
\hline $12: 20$ & 223 & 7.08 \\
\hline $12: 30$ & 224 & 6.67 \\
\hline $12: 40$ & 223 & 7.08 \\
\hline $12: 50$ & 224 & 6.67 \\
\hline $13: 00$ & 223 & 7.08 \\
\hline
\end{tabular}

Table 9: Measured voltage and evaluated percentage voltage deviation at time interval for machines laboratory.

\begin{tabular}{|c|c|c|}
\hline Time (hr) & Umeasd (V) & U dev (\%) \\
\hline $12: 00$ & 219 & 8.75 \\
\hline $12: 10$ & 220 & 8.33 \\
\hline $12: 20$ & 220 & 8.33 \\
\hline $12: 30$ & 218 & 9.17 \\
\hline $12: 40$ & 219 & 8.75 \\
\hline $12: 50$ & 221 & 7.91 \\
\hline $13: 00$ & 218 & 9.17 \\
\hline
\end{tabular}

Table 10: Measured voltage and evaluated percentage voltage deviation at time interval for power laboratory.

\begin{tabular}{|c|c|c|}
\hline Time (hr) & Umeasd (V) & U dev (\%) \\
\hline $12: 00$ & 215 & 10.41 \\
\hline $12: 10$ & 214 & 10.83 \\
\hline $12: 20$ & 211 & 12.08 \\
\hline $12: 30$ & 212 & 11.67 \\
\hline $12: 40$ & 213 & 11.25 \\
\hline $12: 50$ & 210 & 12.5 \\
\hline $13: 00$ & 215 & 10.41 \\
\hline
\end{tabular}

\section{Conclusion}

Budgetary allocation to the education sector is grossly inadequate with an average allocation of $7.32 \%$ from 2009 to 2018 which is below $26 \%$ of annual budget of any country as recommended by UNESCO. The supply of power to the area under consideration is adequate because the supply covers eight hours per day for forty-five days from $8 \mathrm{am}$ to $4 \mathrm{pm}$ daily. All the six laboratories experience voltage deviations that exceed the normal $\pm 6 \%$ by IEEE standard. Effective teaching in Nigeria is achievable as long as constant power supply is available and in case of power failure, an alternative power source should be provided. The applications of renewable power source such as wind power, solar energy and small hydro power into the existing grid system will go a long way in mitigating the problems associated with incessant power supply which will aid effective teaching of technological education in the country.

\section{Recommendations}

1. Faults on power lines should be cleared without delay.

2. Application of renewable energy and alternative power supply will help teaching and learning in education sector.

3. Discos should strengthen the present grid system.

4. Adequate funding of power and education sectors is an added advantage to effective learning.

5. Technical education should be given adequate attention by the way of maximum funding since this sector is the bedrock of development of any nation. 


\section{References}

1. Adeoye OS, Adebayo AA (2018) Evaluation of energy supply and demand side management for residential buildings in Ekiti State, Nigeria. Innovative Energy and Research 7(1): 1-4.

2. Akanniwor GIK (1998) Electrical power outages and the teaching and learning process in technical training institutions in river state.

3. National Economic Empowerment Development Strategy (NEEDS) (2005) National planning commission, Abuja, Nigeria.

4. Umunadi EK (2011) Students use of electricity in electrical and electronic works. Journal of Education and Practice 2(3): 63-73.

5. Robinson RN (2012) Technology education: The means to realization in Nigeria's vision 2020. Global Journal of Education Research 11(1): 7-13.

6. Ayodele AS (1992) Public enterprises institution reform, the PHCN and electricity development in Nigeria. An Economic Analysis, A commissioned paper, PHCN District Commercial Managers' Workshop.

7. Gupta JB (2008) A course in power systems. Kataria SK and sons (Eds.), 61/23 ansari Road, Daruya Gani, New Delhi, India, pp. 1-643.

8. Bello-Schunemann J, Porter A (2017) Building the future: Infrastructure in Nigeria until 2040. Institute for Security Studies, West Africa Report.

9. Ebhota WS, Tabakov PV (2018) Power inadequacy, the thorn in economic growth in Nigeria. International Journal of Applied Engineering Research 13(16): 12602-12610.

10. El-Hawary ME (2000) Electrical energy systems, Dalhousie University, CRC press, Bocaraton, Washington DC, USA, pp: 1-361.
11. Labo (2010) Investors forum for privatization of PHCN successor companies current state and feature outlook of transmission network. Pp. 1-16.

12. Adeoye OS, Okereke CO (2018) Investigation and analysis of reliability of power supply in Ado- Ekiti metropolis, Ekiti State, Nigeria. Research Journal of Energy and Power Engineering 1(1): 1-3.

13. Mehta VK, Mehta R (2008) Principles of power system. Chand and Company-Limited, Ram Nagar, New Delhi, USA, pp: 1-577.

14. Usoro EB (2000) Women in vocational education. Journal of Women in Academics 1(1).

15. Adebayo B, Adebayo AA (2006) Technical education: A necessity for poverty alleviation among the youths. $6^{\text {th }}$ Annual Conference of Academic Staff Union of Polytechnics.

16. Sharyn ON (2009) Effective teaching: An initiative of the director general's classroom first strategy. The Government of Western Australia, Australia, pp. 1-4.

17. https://federation.Edu.au/staff/learning-and-teaching/teachingpractice/what-is-effective

18. Mary HW (2018) Effective teaching strategies: Six keys to classroom excellence.

19. https://www.edb.gov.hk/en/curriculumdevelopment/kla/technologyedu/indexhtml

20. Awosope CA (2014) Nigeria electricity industry: Issues, Challenges and Solutions, $38^{\text {th }}$ Public Lecture, Covenant University, Nigeria, pp. 1-40.

21. www.vanguardngr.com/2018/04/education-free-fall/amp/ 